\title{
Origins of the North Korean Garrison State: The People's Army and the Korean War. By Youngjun Kim. New York: Routledge, 2018. xxii, 248 p [ISBN: 9781137842157]
}

Tomer Nisimov*

The Korean War (1950-1953) is generally seen as the first major clash of the global Cold War, and as such, it has received broad attention in scholarly circles. Its military and political aspects - mainly those involving the three powers, the USA, the USSR, and China - have been well covered in scholarship throughout the decades. Yet only since the last decade of the twentieth century, thanks to the end of the Cold War, the declassifying of archival materials in Russia, and the growing of attention and treatment by scholars from China, the field has gained new insights and perspectives about this civil war that had quickly escalated into a global war. Although the crucial role of China in that war received the important attention of works in recent years thus enhancing the role of the powers of that time, ironically, the Korean bellicose sides have been predominantly perceived and treated as minor players. Bruce Cuming's classic two volume work about the Korean War (The Origins of the Korean War) set an important course in the scholarship for uncovering local and broader aspects. In this sense, Kim Youngjun has succeeded not only in

* Tomer Nisimov is a PhD student at the Department of History, Princeton University. His research interests lie in twentieth-century geopolitics and history of Northeast Asia 
adding a new perspective to our understanding of that war, but more importantly, uncovering the account of North Korea and explaining the relationship between the state, the political elite and the people to the Korean War. In addition, the crucial military aspect of the North Korean revolution, including both the military build-up and the militarization of the society, has become the main theme of the book. This fills an important gap in the literature that was only briefly treated in former works of historians of North Korea such as Bruce Cumings' The Origins of the Korean War and Charles Armstrong's The North Korean Revolution, 1945-1950. ${ }^{1}$

The book renders a convincing analysis regarding North Korea's military preparations before the war highlighted by the creation of the Korean People's Army (KPA), its mistakes and successes during the war, and finally how the management and results of the war have shaped North Korea since then. Kim Yongjun points out the many errors at the commanding as well as operative levels, its lack of sufficient logistical preparedness and training, and inaccurate appraisals by Kim Ilsŏng and the North Korean leadership. Nonetheless, the creation of the KPA is considered to be quite successful in light of its development within a short period of five years and other merits demonstrated on the battlefield.

Origins of the North Korean Garrison State is a comprehensive study about the creation and the development of the KPA in the years prior to the Korean War (1945-1950), and its politicization by Kim Ilsŏng during the war. The author has gathered and concentrated valuable information from various sources, many of which were unexamined, and thereby succeeded in exposing new details about the commanders and soldiers who served in the KPA. Kim thus answers questions regarding the KPA's pre-

1 See: Bruce Cumings, The Origins of the Korean War, Vol. I: Liberation and the Emergence of Separate Regimes, 1945-1947 (Princeton: Princeton University Press, 1981), and The Origins of the Korean War, Vol. II: The Roaring of the Cataract, 1947-1950 (Princeton: Princeton University Press, 1990). See also: Charles K. Armstrong, The North Korean Revolution, 1945-1950 (Ithaca: Cornell University Press, 2004). 
paredness for war, its different tactics, strategies and overall performance during the war. Therefore, it is an important and much welcomed contribution both for the fields of Korean history and military history as well. Four main arguments are raised in the book, but the most important and novel is the one concerning the change in perception of the North Korean regime following its military debacle and growing tensions between itself and its allies - the USSR and China - as well as the humiliation caused by them. Kim Youngjun argues that through the experiences of the North Korean leadership and people during the Korean War, the KPA became the consolidating force between them and, hence, not only the most important institution in North Korea because of its might against external and internal threats, but also because of its symbolic meaning shared by both sides of the social hierarchy. This transcendency of the KPA was made possible from the time of the war and onwards due to Kim Ilsŏng's propagation of what the author calls a "community spirit of victimization," which has been identified with North Korea since then. I will touch specifically upon the rest of the arguments below. In a unique and insightful manner, the book enhances our understanding about how the North Korean state was created as we know it today, and of no less significance, it tells about the unusual relation between the leadership and the common people, which is often hard to grasp for an outside observer.

The author has made use of wide-ranging sources, most notably of which are documents from North Korea that were seized by the US Army in 1950 and are now found at the US National Archive. Of particular interest, Kim Youngjun also utilizes biographies, memoirs and interviews of former KPA soldiers that had participated in the Korean War. Kim has also utilized archival sources in the Russian language, some of which are found at the Woodrow Wilson International Center for Scholars and some of which were given by the Russian government to South Korea in the 1990s and ended up in Seoul. While the scope of the sources used in this book - and particularly the archival ones - is very impressive, I would have generally referred to the lack of use of archival materials of the Republic of China (ROC) in Taiwan, of which are the very useful Academia 
Historica (Guoshiguan 國史館) and the Kuomintang Archives (Dangshiguan 黨史館). Many relevant sources - mainly intelligence reports - are found there, that can contribute greatly to the knowledge about North Korea in the late 1940s. It seems surprising to me that following the conclusion of WWII, the fact that many Korean activists chose to stay in China and operate there (and some even served as agents in North Korea and Manchuria) remains unknown in the scholarship. ${ }^{2}$ The potential use of such sources would, undoubtedly, expand our knowledge about and understanding of North Korea and fill even more gaps that exist.

The book is divided into two parts, the first one with six chapters that untangle the different origins of the KPA prior to the liberation of Korea in August 1945 and its build-up from the time of liberation to the Korean War. The second part consisting of two chapters concerns the different impacts the Korean War had on North Korea, and how these have ultimately shaped the relations between the regime and the common people, and finally to what the author refers to as the North Korean "garrison state." It extensively covers the different origins of the KPA, and the author argues that the KPA was not a creation of the USSR, but instead it had various origins and heritages, the Soviet not being the only one as it also included Chinese and even Japanese influences. Although this argument is important in any discussion about the KPA, it should be pointed out that it is not a new discovery, but in fact, well known from previous studies about North Korea by Bruce Cumings and Charles Armstrong,

2 Several intelligence documents found at the Kuomintang Archives (Dangshiguan) 黨史館 in Taiwan reveal some of the details regarding the identity of those Korean activists who stayed in China following the conclusion of WWII. A considerable part of them were members of Kim Ku's (金九, 1876-1949) Korean Independence Party (KIP; 韓國獨立黨, Han'guk Tongnip Tang). They and others who had joined them, had operated in Northeast China and North Korea in the late 1940s. These activists and agents have provided valuable information regarding the situation in North Korea and the Korean communities in Northeast China at that time, as can be seen for example from the following report: Min Suk Nin, Mar. 1947, Dangshiguan, Special record 16/26.7. 
and also in other works by Chinese authors such as Shen Zhihua. ${ }^{3}$ Nonetheless, the author also highlights the important aspect of social mobility of the lower classes of North Korean society due to recruitment to the $\mathrm{KPA}$, an aspect that has received less attention in former studies that concentrated more on social mobility via economic and political channels. The author also underlines Kim Ilsŏng's own role in preparing the KPA for war and at the outbreak of the Korean War, which on the one hand is generally accepted, but on the other hand it seems that at times the author gives too much credit to Kim Ilsŏng and downplays the roles of Kim's comrades and Soviet advisors. While these arguments are indeed important for the themes covered in the book, it should have been pointed out that some of these are not original arguments by the author, but instead, his own research and conclusions further strengthen arguments made by other scholars.

The first chapter aims at refuting some of the misconceptions in the scholarship of the Korean War that have been accepted for many years. One of these main misconceptions about the Korean War that has shaped the view of the military balance during the outbreak of the war is the "element of surprise." Kim aptly highlights the fact that the Korean people did not find themselves in a state of war only after June 25, 1950, and that supposedly Korea was peaceful before that date. On the contrary, Korea was already in a state of intense conflict, albeit limited, from 1948 to 1950, and it was clear to all sides - the South and North, as well as their patrons the USA and the USSR - that these armed conflicts of guerrilla warfare and clashes along the $38^{\text {th }}$ parallel could well develop into an allout war. For most of the Korean people, Kim argues, it was more a disappointment rather a surprise, since the conflicts developed into an all-out war and evolved quickly into an international war. Moreover, the author

3 See: Cumings, 1981, 414; Armstrong, 2004, 234; Shen Zhihua 沈志华, Mao Zedong, Sidalin yu Chaoxian Zhanzheng 毛泽东, 斯大林与朝鲜战争 [Mao Zedong, Stalin, and the Korean War.] (Guangzhou: Guangdong renmin chubanshe, 2003), 187-190. 
maintains that some of the claims raised in American works regarding the US Army being unprepared for the war are untrue. According to Kim, the problem was not the US Army's lack of preparedness as it enjoyed military and technological supremacy, but rather, it was a substantial lack of intelligence assessment. The US Army was aware of the gradual expansion of the KPA and the possibility of a conflict, however, it inadequately perceived this army as a deficient force that was mainly composed of peasants. According to Kim, the same assessment took place with regards to the Chinese People's Volunteer Army (commonly referred to as the CPVA, however the author chose to refer to this force as the CVF) when China entered the war. Another important aspect that the author adds here is the political failure of the South Korean government under Lee Syngman (1875-1965), which could not make timely crucial decisions and was virtually paralyzed until the US Army intervened.

Chapter 1 also covers the preparations and pre-planning of the war by the North Korean leadership. The author points out the fact that the North Korean leadership had not fully reached a consensus regarding war plans or goals such as the scope of the war and whether the offense should aim at a national war of liberation or a limited war aimed at collapsing the Lee Syngman's regime. It also highlights the initial difficulties and limitations of the KPA, particularly with respect to its chain of command, logistics, and its incompetence to wage a prolonged war. The author makes another good point in his emphasis on the various heritages of the KPA and the impacts the USSR and China had on it, such as different fighting experiences, strategies and tactics, and how these influenced the performance of the KPA. He argues that Kim Ilsŏng aspired to make use both of the "modern and scientific" fighting methods and strategy of the Soviet Army, alongside the guerrilla tactics that were identified with the Chinese Communists, however, the topography of the Korean peninsula was unsuitable for adopting the Soviet military doctrine of "Deep Operation," and at the same time the KPA was neither capable of waging a prolonged war like the Soviet Army. Yet another important issue that is raised in the chapter is regarding manpower of the KPA on the eve of the war. There is no 
agreement about the total number of Korean soldiers who came to North Korea up to 1950 from the People's Liberation Army (PLA). Bruce Cumings estimates as high as 100,000 Korean soldiers whereas Chen Jian estimates somewhere between 50,000 to $70,000 .{ }^{4}$ In sum, this chapter might change what one had thought about the early failures of the Korean War on the Allies' side, and contributes greatly to our understanding of the situation in North Korea on the eve of the war.

In Chapter 2 the author traces the different origins of the KPA, which was comprised of guerrilla fighters from Manchuria who had fled to the USSR in the early 1940s, other Koreans who had fought alongside the Communist Party of China (CPC) and had participated in China's Civil War, and yet another group of Koreans who fought in the Soviet Army during WWII who were part of what is known as the "Soviet Koreans" or "Soviet (Koreans') faction" in North Korea. The latter group was comprised of Soviet Koreans who had returned to North Korea from the USSR following the occupation of the North by the Soviet Army and were mainly civilians with technical backgrounds who filled the different offices in the developing regime such as in the government, bureaucracy, academic and higher educational institutions, and more. ${ }^{5}$ But in spite of the reference by the author to those Koreans who came from the Soviet Army and participated in WWII (and giving only a handful examples for such people), it remains unclear what was the scope and the influence of this group. In this regard, it would be much welcomed and helpful for the studies of North Korea to draw on more sources from the Russian language in order to understand these questions about the Soviet-Koreans, and to try to understand what kind of impact they had on North Korean society and politics, while keeping in mind their degraded status and their

4 Cumings, 1990, 363; Chen, China's Road to the Korean War: The Making of the Sino-American Confrontation (New York: Columbia University Press, 1994), 110.

5 See Andrei Lankov's outline regarding the Soviet Koreans for further details: Andrei Lankov, From Stalin to Kim Il Sung: The Formation of North Korea, $1945-$ 1960 (New Brunswick, NJ: Rutgers University Press, 2002), 80-92, 110-135. 
suffering from social and vocational restrictions in the USSR due to their purge in the 1930s.

The author devotes a substantial part of this chapter to elaborating on the Korean veterans from China's Civil War, who were generally known in China as the Korean Volunteer Army (KVA) and whose political leaders constituted the "Yan'an faction" in North Korea. This was indeed a very significant group that the author has aptly paid attention to throughout the book. One point of interest that the author raises is the issue of permitting the KVA veterans to enter North Korea in the interim period following the end of WWII and prior to the Korean War. Earlier studies have pointed out that in late 1945 only a few dozen Korean veterans were allowed to enter North Korea, albeit disarmed by the Soviet Army. ${ }^{6}$ Kim Youngjun asserts that due to Kim Ilsŏng's past connection to the CPC, the Soviet Occupation Authorities in North Korea (SOANK; or otherwise known as the Soviet Civil Administration) were concerned that a potential symbiosis between Kim Ilsŏng and the KVA veterans - who were seen as a proxy of the CPC - might harm the Soviet political leverage over North Korea. As a result, the author argues, it was only after the Soviet Army withdrew from North Korea in December 1948 that it allowed substantial elements of the KVA to enter North Korea. ${ }^{7}$ While the assumption is not necessarily wrong, I would rather have suggested a few more factors that definitely could explain the cause of the return of the Korean forces to North Korea. First, it should not be forgotten that from August 1945 to May 1946, the Soviet Army was still in Northeast China and even had some presence later than that in such locations as Harbin and Dalian. At the same time, we know that the KVA was also operating in approximate regions in Northeast China and the possibility of contact between them,

6 The different accounts vary on the question of the number of and the way the KVA veterans had returned to North Korea in late 1945. Here I refer to a few sources that mention that issue: Cumings, 1981, 412-413; Shen, 2003, 187.

7 Kim Youngjun, Origins of the North Korean Garrison State: The People's Army and the Korean War (New York: Routledge, 2018), 41. 
either directly or indirectly through the CPC, should not be neglected, as intelligence reports of the Guomindang (GMD) indicate that there was communication between the three groups.

Another possibility is, as Bruce Cumings has pointed out, that the USSR was concerned of violating its agreement with the USA by allowing armed Korean forces to enter the peninsula or, at least, that it would become known. ${ }^{8}$ The fact that numerous KVA veterans entered North Korea in late 1948 and afterwards has a lot to do with timing: first, by November 1948 the CPC had defeated the GMD in the LiaoShen Campaign in the Northeast; and secondly, right after the LiaoShen Campaign the Soviet Army withdrew from North Korea partly due to that victory, making the KVA's entrance possible since the Soviets were virtually absent in North Korea and could not take responsibility on the matters there anymore. I have shown elsewhere that even as early as 1947, the North Korean leadership had already negotiated with the CPC about the repatriation of Korean veterans from the Northeast Democratic Allied Army (NDAA). But it was the CPC's Northeast Bureau and its commander Lin Biao (1907-1971) who turned down North Korea's request at the time since they wanted to make further use of the Korean soldiers in the upcoming battles against the GMD, and the Soviet Army assumed the role of mediator between the two sides. ${ }^{9}$

Although Chapter 2 covers the different origins of the KPA in length, the author has not addressed the question of North Korean intervention in the Civil War in China, and the question over if it sent troops to Northeast China. This issue is relevant not only to the study of the KPA's development and competence prior to the Korean War, but also to the question of the KVA's potential influence in North Korea. Did Kim Ilsŏng decide to send troops to Northeast China, thus reinforcing the military capability of

8 Cumings, 1981, 413.

9 Tomer Nisimov, "The Role of North Korea in China's Civil War: The Soviet-led North Korean Assistance to the CPC in the Northeast Theater, 1946-1948," Journal of Chinese Military History 9, no. 1 (March 2020), pp. 87-88. 
a force more loyal to him, and at the same time increasing his own prestige in North Korea? Moreover, North Korea's involvement in the military and social mobilization of the Korean population of Northeast China during the civil war requires further exploration as current scholarship lacks any reference on that point.

In Chapter 3 the author explains how the pre-1945 experiences of Kim Ilsŏng shaped his vision for the future independent Korean army. Among these, the author covers three major episodes: the Minsaengdan Incident, the guerrilla activity in Manchuria in the 1930s, and the years of service in the Soviet Far East during the early 1940s. The author indicates, like Charles Armstrong and Park Hyun Ok before him, ${ }^{10}$ that the Minsaengdan Incident was a turning point for many Korean Communists such as Kim Ilsŏng in their pursuit for autonomy from their Chinese comrades, and later from other powers when North Korea was established. Each of these, the author argues, had a contribution to the set of goals and features that Kim Ilsŏng later designated for the KPA. Kim Youngjun shows how the activity in Manchuria along the Chinese Communists shaped Kim Ilsŏng's ideology and military thinking, emphasizing guerrilla warfare tactics and the "people's war," altogether referred by the author as "Chinese cultural influence," while the years under the Soviet Army led him to appreciate the effectivity of a modern and sophisticated army, which the author refers to as "Soviet material culture." It remains unclear, however, why the author has decided to designate these influences as cultural, while in reality they reflected elements of ideology and material reality. For example, it was Mao's thought that stressed the people's role in warfare, and it was the lack of advanced weapons and military institutions i.e. the material reality - that handicapped the Chinese and Korean Communists from fighting as a modern force and not cultural attributions. In sum, the author argues that due to Kim Ilsŏng's dual legacies - the com-

10 Armstrong, 2004, 27-32; Park Hyun Ok, Two Dreams in One Bed: Empire, Social Life, and the Origins of the North Korea Revolution in Manchuria (Durham: Duke University Press, 2005), 201-203, 221-230. 
bination of modern tactics and weapons identified with the Soviet Army and the "people's war" identified with the CPC--potentially could have maximized the efficiency and performance of the KPA, even if the concepts were contradicting. However, due to other failures as explained, that was not the case.

In the following two chapters, Kim Youngjun elaborates more on the Soviet influence over the KPA. He claims that former studies about North Korea have largely focused on the Soviet role in developing the KPA, but not on other factors such as the Chinese role. However, given the number of references to the KVA and the Yan'an faction in virtually every major work about North Korea and the Chinese influence on them, even if less detailed than this book, this assertion seems fragile. ${ }^{11}$ Kim Youngjun also attempts to argue that the ones responsible for creating the KPA were the North Korean elite and the USSR. Again, it seems that the author wishes to give more credit to Kim Ilsŏng and to downplay the Soviet role. But eventually the creation of the KPA was possible due to a combination of factors, of which, the Soviets must be included: without the Soviet material and advisory assistance the KPA would have not become the force it did by 1950, in spite of Kim Ilsŏng's vision. The USSR had actively armed and trained the Korean forces in the North, established military schools in the North, and had sent many North Korean youths for technical and military training to the USSR. Therefore, the scope of Soviet training, counsel, and influence could barely be labeled as "Soviet material culture" alone. It seems as if the author was mostly concerned about the KPA's indigenous features and its independent nature, but these less likely were of concern for the USSR, which was mainly occupied with ensur-

11 References to joint activity between Chinese and Korean Communists, and the former influence on the latter, can be found in other works, such as: Lankov, 79-80; Lee Chong-sik and Robert Scalapino, Communism in Korea: Part I: The Movement (Berkeley: University of California Press, 1972), 175-179; James Minnich, The North Korean People's Army: Origins and Current Tactics (Annapolis, Maryland: Naval Institute Press, 2005), 17-18; Shen, 2003, 187-189. 
ing North Korea's military development, ability to defend itself and, if needed, to carry out an offensive. These were all part of the Soviet strategic thinking in postwar Northeast Asia. Yet in another aspect it seems that the author attempts to give more credit to Kim Ilsŏng by downplaying the role of the Soviet advisors and emphasizing Kim's own carte blanche control, however it is not widely accepted and probably not plausible that Kim Ilsŏng controlled so comprehensively prior to $1948 .{ }^{12}$ The author reasons Kim Ilsŏng degree of autonomy from Soviet control was due to the supposedly lesser role Korea played in overall Soviet strategy in contrast to Eastern European countries at that time. Even if Korea was of secondary importance in the Soviet calculations, it is still not probable that it would cede effective control to inexperienced leadership. I would point out the case of Cho Mansik (1882-1950) in stressing how difficult it was for the SOANK to work with local leaders, which very likely reinforced their determination not to cede control so easily. Therefore, if North Korea enjoyed a degree of autonomy from Moscow during the first few years, it might had served the Soviet advisors, and not Kim Ilsŏng and his guerrillas. Ultimately, between the years 1945-1948, any major decision had to be approved by the Soviet advisors.

Chapter 5 provides one of the most original and important analyses that explains the weaknesses and disadvantages of the KPA. The author argues that the adoption of the Soviet military doctrines, strategies, and institutions by the KPA were not adequate due to various factors. He discusses the development of the Soviet Red Army during its two most crucial and influential events: the Russian Civil War (1917-1922) and WWII. Kim Youngjun gives the example of the Soviet Army's system of military commissars, and explains the context in which this system was developed and why it did not fit North Korea's context. Therefore, not only was it not useful, but it was also a burden for the commanding mechanism. Ac-

12 Regarding the level of Soviet control and decision making in North Korea during the years 1945-1948, see: Andrei Lankov, The Real North Korea: Life and Politics in the Failed Stalinist Utopia (New York: Oxford University Press, 2013), 6-8. 
cording to the author, however, the KPA suffered from other more crucial deficiencies at the time of the outbreak of the Korean War, particularly the lack of an effective commanding structure like the Soviet Army had and which was to oversee the logistical and economic channels of the war. Also, the KPA was unable to wage a prolonged war, unlike the Soviet Army, in spite of the KPA's rapid development and modernization in a very short time.

In Chapter 6 the author contrasts the "temporary business partnership" between the USSR and North Korea with the "long-term personal friendships" that supposedly characterizes the Sino-North Korean relationship. The whole probability of Sino-North Korean conflicts of interest and competition is still significantly absent in the secondary literature, and therefore leads to an inaccurate perception about the nature of their relations. China and Korea indeed have more cultural and historical connections than the USSR and Korea, and the Korean Communist Movement indeed had much closer ties to the Chinese Communists, but this does not ensure that conflict and suspicion do not exist. ${ }^{13}$ It seems that the author has missed the point that following Japan's defeat, not only the GMD discriminated against the Korean population in Northeast China, as suggested by him, ${ }^{14}$ but in fact the Chinese common people in general and, according to intelligence reports, even the Chinese Communists themselves discriminated against Koreans. ${ }^{15}$

13 Regarding tensions between the Chinese and Korean Communists prior to the Korean War, see my book review about Sino-North Korea relations: Tomer Nisimov, "book review of A Misunderstood Friendship: Mao Zedong, Kim Ilsung, and Sino-North Korean Relations, 1949-1976, by Zhihua Shen and Yafeng Xia, New York: Columbia University Press, 2018," International Journal of Korean History 25, no.1 (February 2020) (https://ijkh.khistory.org/journal/view.php?number=527). See also my forthcoming article about the Korean Volunteer Army and the CPC: Tomer Nisimov, "Troublesome Brotherhood: The Korean Volunteer Army and the CPC," Journal of Northeast Asian History (forthcoming).

14 Kim Youngjun, 2018, 147.

15 In a report to the GMD by a member and delegate of the Korean Independence 
The other side of the comparison between the USSR and the CPC is the nature of Chinese influence. The author is right in pointing out that due to their close relations with and influence by the CPC tens of thousands of Koreans by the late 1940s served as a conduit to pass the Chinese Communist ideology and fighting techniques to the KPA. At the same time, these Korean soldiers gained experience in the Civil War in China, which was undoubtedly important for the KPA's performance. In spite the fact that this was mainly an abstract influence and not materials as the Soviet Army had provided, it still was very consequential for the KPA. The problem of course was political since Kim Ilsŏng and his inner circle could not fully trust the Korean veterans from China. Therefore, in spite of the KVA veterans' superior military experience, they were by and large excluded from top positions in the military and from taking part in planning the attack against the South. Even during the war itself, the units of the KPA that were formerly part of the KVA were many times excluded from major battles due to concerns of rivalry over political power and prestige. Instead, they were used as auxiliary forces while considerably less experienced but loyal Kim Ilsŏng forces were sent to important fighting zones. This is another strong point of the book where the author shows how the KPA could potentially have made use of this experienced element, yet due to political calculations the overall KPA's performance was hampered.

The second part of the book moves away from the theme of the origins of and the different influences on the KPA, to discuss two intertwined processes that occurred during the Korean War: the politicization of the KPA and the militarization of North Korean society. In Chapter 7 the au-

Party to Northeast China from March 1947, it is pointed out that, for example, many Korean farmers in Northeast China have fled their villages as refugees following the CPC's harsh and destructive policies and measures towards them, and that they have reached out to territories under the control of the GMD. The report also mentions that the CPC had confiscated property from the Korean farmers. See: Min Suk Nin, Mar. 1947, Dangshiguan, Special record 16/26.7. 
thor explains how due to the military failure of the KPA and the intervention of the CPVF beginning in October 1950, Kim Ilsŏng was forced to reinforce the politicization of the KPA (which was possible mainly with the establishment of the General Political Bureau) and to militarize North Korean society in order to maintain complete control over the KPA and his leadership. Following the defeats on the battlefield and due to the fact that North Korea could not continue the war on its own, the KPA became de facto subordinated to the CPVA and its commander Peng Dehuai (1898-1974). Kim Ilsŏng became worried that this would expand the influence of the Chinese Communists and their old comrades from the Yan'an faction. Thus, Kim Ilsŏng worked to guarantee the control of the Korean Workers' Party (KWP) over the KPA.

Simultaneously, the author notes, Kim Ilsŏng also bolstered the control of the KWP over the guerrilla forces in the South that were associated with Pak Hŏnyŏng (1900-1955), and elaborates further on that point in the next and last chapter, pointing out the close coordination and military plans for the regular forces - the KPA - and the guerrilla forces, which together improved the military effectiveness and performance of the North. The author also writes in detail about senior commanders of the KPA from Kim Ilsŏng's guerrilla group and from the Yan'an faction, and explains that at this point as Kim Ilsŏng thwarted accusations and criticism for military failures, he was looking for scapegoats and did not hesitate to purge even some members of his own group, albeit most of the purges were directed against members of the Yan'an faction. Therefore Kim Ilsŏng was able both to avoid criticism and to remove potential challenges to his rule.

If in Chapter 7 the author shows how Kim Ilsŏng became worried and felt humiliated by the growing influence of his ally China, in Chapter 8 he shows the impact of the American bombing campaign on the North Korean regime and how that reshaped the relationship between the North Korean regime and its people. Humiliated by his allies and destructed by his enemies, the author argues that due to this predicament, Kim Ilsŏng worked on consolidating his power through last resort measures such as 
cultivating a "community spirit of victimization." In a similar fashion of scapegoating his army commanders, Kim Ilsŏng refuted the fact that North Korea started the war, and therefore, he and the leadership were not responsible for the huge destruction that was brought upon the Korean people throughout the course of fighting. The author convincingly argues that through the traumatization of North Korean society and the humiliation of the leadership, the common sentiment of victimization reinforced the ties between the leadership and the common people with the KPA as the link that guaranteed the protection of the people. He also points out that this spirit of victimization served as one of the factors that brought about the rise of Juche ideology and the isolation of North Korea.

In other parts of Chapter $8 \mathrm{Kim}$ Youngjun analyzes the performance of the KPA during the war in light of different assessments regarding its effectiveness. In a very skillful and careful manner, the author attributes the KPA's different levels of performance to their distinct origins, and in some cases, the lack of time in preparation and training before the war due to the haste of Kim Ilsŏng. Nonetheless, he also highlights that some of the KPA units fought successfully on the tactical level and that the KPA soldiers were usually disciplined and had a good fighting spirit.

Altogether, the author has utilized a variety of important sources and gathered valuable information that definitely makes it a much-welcomed scholarly work in the field of North Korean history. Kim Youngjun has made very important and original arguments that touch upon several themes at the same time: the Korean War, the development of the North Korean military, North Korean society, and the consolidation of the Kim family's regime. In all these matters the author contributed an enlightening and novel interpretation, which I am certain will benefit the studies of North Korea and scholarly works to come. In spite of all of these strongpoints, the book unfortunately suffers from several errors. A recurring problem throughout the book is that of wording and spelling. Some of the sentences are repetitive and their meaning is rendered in the following paragraphs in an unnecessary manner.

But a bigger issue is definitely the one of spelling: in many cases the 
author prefers to use the Korean pronunciation for Chinese names, which is confusing for the non-Korean reader. Some examples include Kukmindang instead of Guomindang, Jangchun and not Changchun, Gilim and Jilin, etc. Many of the names of the figures mentioned in the book were not spelled consistently in the same way. The author has also created his own unusual terms such as "Korean Chinese [Communist Forces]" instead of "Sino-Korean." At times, as mentioned above, the author has credited Kim Ilsŏng probably too much for actions and decisions that were clearly beyond his sole will. Unfortunately, the author has made it seem as if all the four main arguments in the book are originally proposed by him, where in fact previous studies have already made the same points. The author should have indicated whether a certain argument or crucial point is his own or of another scholar, and if it is the latter, then he should have pointed out how he strengthens his point or argument with his new findings. 
